\title{
Sources and Distribution of Mercury Residues in Environmental and Food Matrices of the Mekrou River Watershed in Kèrou, Kouandé and Péhunco in Republic of Benin
}

\author{
Alassane Youssao Abdou Karim ${ }^{1, *}$, Mahamadou Daouda ${ }^{2}$, Abdoul Kader Alassane Moussa ${ }^{3}$, \\ Daouda Mama ${ }^{3}$, Issaka Youssao Abdou Karim ${ }^{4}$ \\ ${ }^{1}$ Department of Chemical Engineering-Processes, Polytechnic School of Abomey-Calavi, University of Abomey, Calavi, Bénin \\ ${ }^{2}$ Department of Animal Feed and Nutrition, Faculty of Agronomic Sciences, University of Abomey, Calavi, Bénin \\ ${ }^{3}$ Department of Chemistry, Faculty of Sciences and Technologies, University of Abomey, Calavi, Benin \\ ${ }^{4}$ Department of Animal Production and Heath, Polytechnic School of Abomey-Calavi, University of Abomey, Calavi, Benin
}

Email address:

youssaoalassane@gmail.com(A.Y.A.Karim), dahouda2605@hotmail.com(M. Daouda), almokano@gmail.com(A.K.A. Moussa), mkdaouda@yahoo.fr(D.Mama),iyoussao@yahoo.fr(I. Y.A. Karim)

${ }^{*}$ Corresponding author

\section{To cite this article:}

Alassane Youssao Abdou Karim, Mahamadou Daouda, Abdoul Kader Alassane Moussa, Daouda Mama, Issaka Youssao Abdou Karim. Sources and Distribution of Mercury Residues in Environmental and Food Matrices of the Mekrou River Watershed in Kèrou, Kouandé and Péhunco in Republic of Benin. American Journal of Applied Chemistry. Vol. 6, No. 2, 2018, pp. 57-63. doi: 10.11648/j.ajac.20180602.14

Received: March 28, 2018; Accepted: April 17, 2018; Published: May 8, 2018

\begin{abstract}
Environmental scientific research has been largely developed for about a century, and many disciplines have been interested in interactions and the role of hazardous chemical elements such as metallic mercury and its inorganic and organic compounds in the environment. This study aims to assess the mercury contamination level of some foodstuffs (water, milk) and of the terrestrial and aquatic environment (fodder, agricultural soil and sediments) in the municipalities of 2KP. Total mercury (T-Hg) has been determined by DMA-80 (Direct Mercury Analyzer) in different environmental and food matrices of the Mekrou river watershed in Kèrou, Kouandé and Péhunco (2KP municipalities). The mercury content is higher in the superficial horizon of agricultural soil $(0-20 \mathrm{~cm})$ than in the horizon $(20-40 \mathrm{~cm})$. Watercourses (Mekrou River and its tributaries) have relatively low levels of $\mathrm{Hg}(0.5$ to $1.3 \mu \mathrm{g} / \mathrm{L})$ in water compared with ponds and dams $(181.2$ to $616.9 \mu \mathrm{g} / \mathrm{L})$. Conversely, ponds and dams are characterized by low levels of mercury in water and relatively higher levels in sediments. Concentrations of $\mathrm{Hg}$ in cow's milk and cattle feed varied respectively in the concentration ranges of (0.4 to $8.7 \mu \mathrm{g} / \mathrm{L})$ and (7.1 to $15.7 \mu \mathrm{g} / \mathrm{kg})$. Regarding plant material, the highest concentrations of mercury $(15.7 \mu \mathrm{g} / \mathrm{kg})$ are obtained in the okra leaves (Abelmsehus eseuilleus (L.) Moench) used in the human diet, compared to cattle fodder. This work reveals agriculture as the leading source of mercury ecosystem contamination, followed by Artisanal and Small-Scale Gold Exploitation (ASSGE) and hospital sources in 2KP municipalities.
\end{abstract}

Keywords: DMA-80, Pollution with Hg, Anthropogenic Sources, Kérou, Kouandé, Péhunco

\section{Introduction}

Mercury (Hg), the only liquid and volatile metal in room temperature [1], is a toxic metal pollutant released into the environment by natural and anthropogenic sources [2-4]. It is mainly derived from agricultural activities (pesticides, fertilizers), mineral exploitation and hospital sources and research laboratories $([5,6])$. These sources are not documented in the municipalities of Kérou, Kouandé and Pehunco (2KP). However, the food needs induced by the rapid population growth have created a high agricultural production which has led to an excessive increase in pesticide imports and overexploitation of cropland. In 2007, 
25365 hectares were planted and 63412 liters of pesticides used [7] against 59819 hectares and 149548 liters of pesticides in 2010 [8] in these municipalities. The increase in cultivation areas is followed by the abusive and uncontrolled use of pesticides (herbicides and fungicides), most of which comes from smuggling [9], where they are found to be prohibited or out of date. In agriculture, however, certain mercury compounds are used as antifungal agents that contribute to the release of this metal pollutant into the environment $[10,5]$. In addition to the agricultural sources of $\mathrm{Hg}$, we can identify Artisanal and Small Scale Gold Exploitation (ASSGE) and the use of mercury containing medical measuring instruments, in particular the mercury thermometer.

Indeed, the use of the mercury-containing medical thermometer was spread in Benin with sensitization in hospitals where each child must have his thermometer. Since mercury has the bioaccumulation capacity in organisms, its presence in the environment would lead to the contamination of the various components of the food chain and in particular humans. Among its chemical forms, methyl mercury ( $\mathrm{MeHg}$ ) is the most toxic, which has serious effects not only on the aquatic ecosystem but especially on human health. In the municipalities of $2 \mathrm{KP}$, the use of pesticides for medicinal purposes, the application of pesticides with very weak and / or rudimentary protection measures, the use of the packaging of these pesticides for domestic purposes, the mismanagement of pesticides or medical waste by some hospitals and the exploitation of mining sites in a traditional way are all activities and behaviors that raise questions of research. The Decline of cotton yields and abandonment of depleted land by overexploitation of the latter and the conquest of new unexploited land are apparent consequences of the accumulation of toxic pesticide residues and mercury in particular. For all these reasons, we considered it necessary to study the distribution of mercury residues in certain environmental and food matrices such as: surface water, sediments, cotton crop soil, cattle fodder, okra leaves (Abelmsehus eseuilleus (L.) Moench) and cow's milk in the municipalities of Kérou, Kouandé and Pehunco (2KP) located in the north of Benin. The observed levels of this metal concentration were compared to drinking water quality standards.

\section{Description of Study Site}

The study area of this research takes into account the watershed area of the Mekrou river in the municipalities of Kérou, Kouandé and Pehunco (2KP). It is located between 10 00 'and $1120^{\prime}$ North latitude and between $1^{\circ} 20$ 'and $240^{\prime}$ East longitude (Figure 1). With a population of 289954 inhabitants and an area of $9315 \mathrm{~km}^{2}$, it is limited to the North by Burkina Faso, to the South by the municipalities of Copargo and Djougou, to the West by the municipalities of Natitingou, Tanguiéta and Toucountouna, in the East by the municipalities of Sinendé, Gogounou and Banikoara. Agriculture, livestock, hunting, logging, and gathering are the basis of the local economy in the municipalities of $2 \mathrm{KP}$. In fact, agriculture is the first activity and the first source of income for the populations of this area. The agriculture covers about $80 \%$ of the population and cotton is the main cash crop. Livestock is the second activity of the labor force. The climate is of tropical type characterized by a rainy season which extends from April to September and a dry season going from October to March without forgetting the cold and dry wind with the haze of dust (harmattan) which blows from November to February. It is found in the municipalities of $2 \mathrm{Kp}$ three large permanent watercourses namely, the Mekrou, Alibori and Pendjari with torrential downpour tributaries.

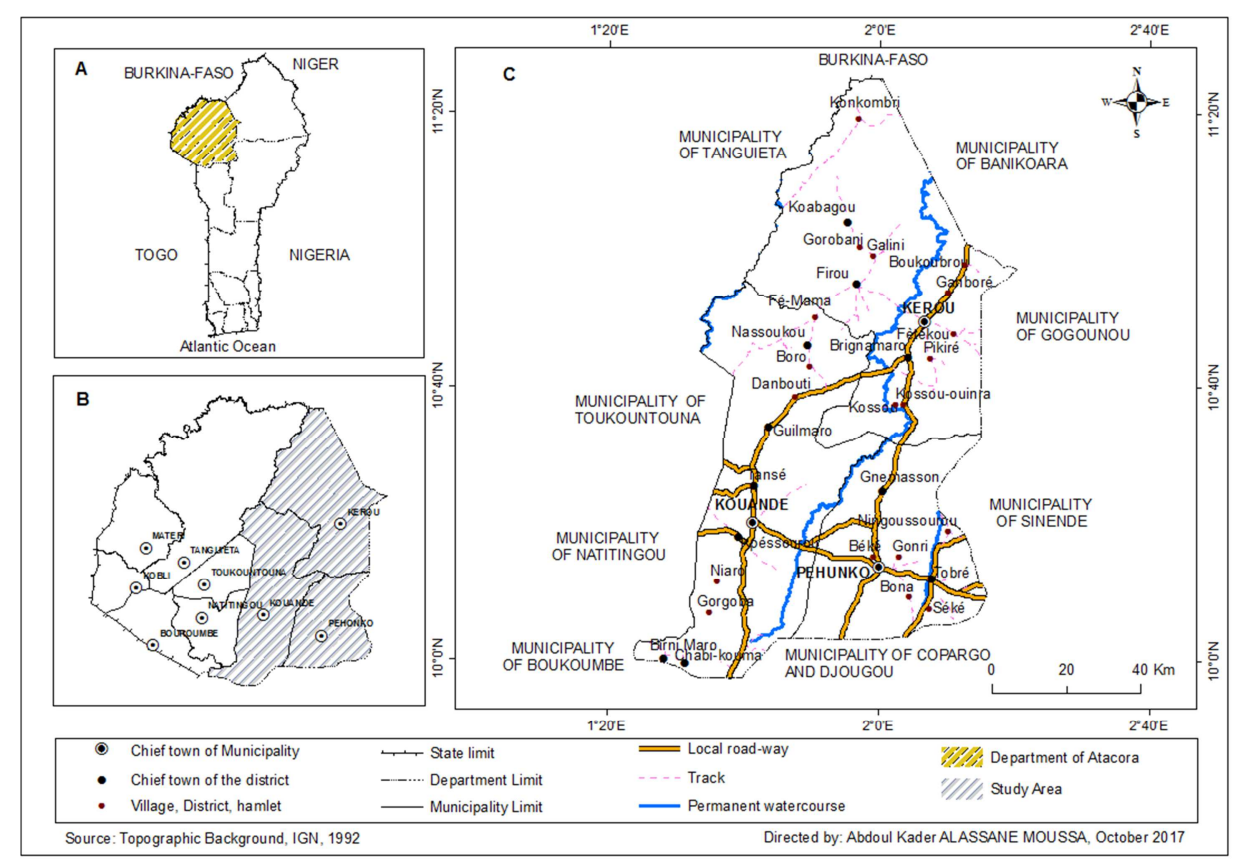

Figure 1. Geographical and administrative location of $2 K P$ municipalities. 
Figure 1. Shows the geographical and administrative location of the 2KP municipalities.

\section{Materials and Methods}

\subsection{Collection of Study Material}

For this research, the study material is composed of surface water samples (river or pond), cow's milk, sediment, cattle fodder, okra leaves (Abelmsehus eseuilleus (L.) Moench) and agricultural crop soil collected in the three municipalities around the Mekrou river. Sampling equipment (vial) was cleaned by the method called "ultra-clean" [11]which consists of cleaning with $15 \%$ nitric acid (HN03), $1 \%$ HCI (ACS grade reagent, JT Baker, Phillipsburg, USA) followed by seven rinses with ultrapure water (Milli-Q system ; > $18 \mathrm{M} \Omega . \mathrm{cm}$ ) and then dried at $105^{\circ} \mathrm{C}$. Agricultural soil samples were collected using dens at five locations on cotton fields, namely at the four corners of the rectangular surface and then in the middle of the field. A composite sample is made with these samples and packed in bags free of contaminants (polyethylene bag) for each of the two levels of depth i.e. 0 to $20 \mathrm{~cm}$ and then 20 to $40 \mathrm{~cm}$ (starting from the soil surface). These samples were labeled before being introduced into a cooler containing cold accumulator. The samples of fodder and okra leave (Abelmsehus eseuilleus (L.) Moench) were collected following the same processes as the agricultural soils (the four corners then in the middle of the field) and transported under the same conditions. Only forages grazed by cows were sampled by varieties, to which we added a variety grown for human consumption in association with cotton and okra leaves (Abelmsehus eseuilleus (L.) Moench).

The water samples were taken from the plastic bottles (polyethylene) previously rinsed with water from the site and then filled to the brim at about $5 \mathrm{~cm}$ from the surface of the body of water. These samples were acidified by adding $2 \mathrm{ml}$ of $\mathrm{HNO}_{3}(65 \%)$ before being completely filled and sealed to prevent gas leakage. The sediment samples (river, fed and dam) were collected using a Chip peck bucket packed in bags free of contaminants (polyethylene bag) and then introduced into a cooler containing cold accumulators. $\left(4^{\circ} \mathrm{C}\right)$.

Cow milk samples were collected from different sellers in different Fulani camps (very early in the morning) and the composite samples stored in 0.5-liter plastic bottles free of contaminants.

\subsection{Samples Preparation and Analysises}

All samples are stored in the laboratory cool and analyzed directly by the MILESTONE Direct Mercury Analyzer (DMA-80) after pretreatment for solid material (soil, sediment, forage, okra leaf) and without any treatment for liquid samples (cow's milk and water). The solid samples were frozen in the laboratory at $-27^{\circ} \mathrm{C}$ for three days. They were then weighed before being freeze-dried for 72 hours at a temperature of - $500 \mathrm{C}$ and a pressure of 12 bar. A sample of $200 \mathrm{~g}$ of each sample of sediment or soil was crushed, homogenized and then sieved using a sieve with a diameter of less than $63 \mu \mathrm{m}$ before the analysis. As for the plant material, it is cut into small pieces before being analyzed with DMA-80 before sampling $200 \mathrm{~g}$ for analysis. For analysis, the samples are placed in a quartz boat on a flat scale and weighed. A mass of soil sample of $100 \mathrm{mg}$ is taken in triplicate and introduced into these boats in the autosampler tray of 40 stations. DMA- 80 is then started to run the analysis. This same analytical methodology was applied for samples of sediment, cow's milk, water, fodder and okra leaves.

\section{Results and Discussion}

\subsection{Concentrations of $\mathrm{Hg}$ in Water and Sediments}

The table below shows changes in average $\mathrm{Hg}$ concentrations in water in the three municipalities. It distinguishes two characteristic zones namely the weakly contaminated samples whose average concentration of $\mathrm{Hg}$ varies from $0.5 \mu \mathrm{g} / \mathrm{L}$ to $1.3 \mu \mathrm{g} / \mathrm{L}$ (Doh3, Pikire1, Pikire6, Kouy1, Seko2, Pikire3) corresponding to the ponds, dams and the peripheries of rivers whose water is relatively stagnant, calm and transparent, and those heavily contaminated with an average concentration of $\mathrm{Hg}$ ranging from $181.2 \mu \mathrm{g} / \mathrm{L}$ to $616.9 \mu \mathrm{g} / \mathrm{L}$ (Beket2, Kos4, Seko1, Kos3, Doh4 , Kouy01, Makrou2) characterized by running water, high flow and disorders.

Table 1. Mean concentrations of $\mathrm{Hg}$ in water $(\mu \mathrm{g} / \mathrm{L})$ and sediments $(\mu \mathrm{g} / \mathrm{kg})$.

\begin{tabular}{llllll}
\hline Code & Water $(\boldsymbol{\mu g} / \mathbf{L})$ & Sediment $(\boldsymbol{\mu g} / \mathbf{k g})$ & Name of river & Surface Water & characteristics \\
\hline Beket2 & 616.9 & 19.2 & - & River** & Plant Crops $* * *$, troubled Water \\
Doh3 & 1.3 & 20 & Flo & River & Periphery, calm \\
Doh4 & 297.8 & 40.1 & Mékrou & River & Low flow, calm \\
Kos3 & 300.3 & 17.4 & Mékrou & River & Periphery, calm \\
Kos4 & 392.3 & 14.8 & Mékrou & River & Running water, troubled Water \\
Kouy1 & 0.8 & 15.5 & Mékrou & River & Periphery, calm \\
Kouy01* & 239.3 & - & Mékrou & River & Running water, troubled Water \\
Makrou2 & 181.2 & 28.8 & Bouanimin & Dam & Running water, troubled Water \\
Piki1 & 0.9 & 19.9 & Mere-Nbougnan & Pond & Stagnant water, calm \\
Piki3 & 0.5 & 24.6 & & Stagnant water, calm \\
\hline
\end{tabular}




\begin{tabular}{llllll}
\hline Code & Water $(\boldsymbol{\mu g} / \mathbf{L})$ & Sediment $(\boldsymbol{\mu g} / \mathbf{k g})$ & Name of river & Surface Water & characteristics \\
\hline Piki6 & 0.9 & 19.6 & Monri-Ndarou & Stagnant river & Stagnant water, calm \\
Seko1 & 308.2 & 12.4 & Beaubora & Running river & Running water, troubled Water \\
Seko2 & 0.7 & 28.1 & Werokogourou & River & Stagnant water, calm \\
Min & 0.5 & 12.4 & - & - & - \\
Max & 616.9 & 40.1 & - & - & - \\
Mean & 180.1 & 21.7 & - & - & - \\
SD & 199.3 & 7.7 & - & - & - \\
\hline
\end{tabular}

* Kouy01 is a site where we could not collect sediment ** - Unknown river name *** Highly developed agriculture 160 in the area. SD: standard deviation.

Caption: The sample code is composed of the three or four initials of the name of the village where the sampling site is located and an identification number (see Table 2).

Table 2. Names of Sampling Villages in 2KP Municipalities

\begin{tabular}{|c|c|c|c|c|c|c|c|c|}
\hline Sample code & Beke2 & Doh3, 4 & Kos3, 4 & kouy1 & kouy01 & Makrou2 & Piki1, 3, 6 & Seko1, 2 \\
\hline Village & Beket & Doh & Kossou & Kouyagou & Kouyagou & Makrougourou & Pikiré & Sekogourou \\
\hline
\end{tabular}

Based on the analysis of the results, sediment $\mathrm{Hg}$ concentrations at different sampling sites in the three municipalities ranged from $12.4 \mu \mathrm{g} / \mathrm{kg}$ to $40.1 \mu \mathrm{g} / \mathrm{kg}$, the highest rate of $\mathrm{Hg}$ in the sediments being obtained at Doh (Doh4).

\subsection{Concentrations of Hg in Soil Horizons, Plant Material and Cow's Milk}

The figure below shows changes in average $\mathrm{Hg}$ concentrations in soil horizons in the three municipalities.

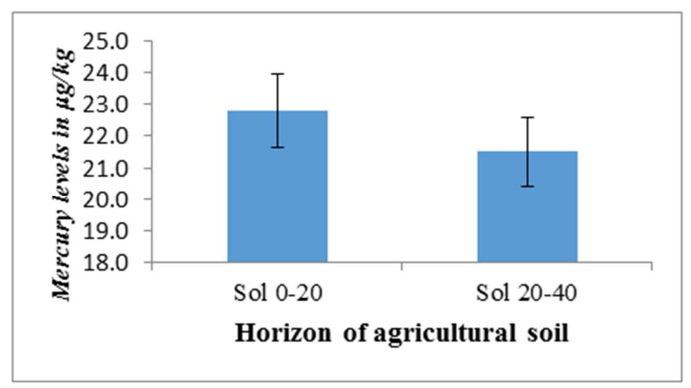

Figure 2. Variations in average Hg concentrations in soil horizons.

Table 3. Average concentrations in livestock fodder collected on cotton soils.

\begin{tabular}{|c|c|c|c|c|c|c|c|c|c|}
\hline Espèces & HIS & IER & AEM & RCL & ACM & Min & Max & Mean & Sd \\
\hline $\mathrm{Hg}(\mu \mathrm{g} / \mathrm{L})$ & 11.4 & 9.1 & 15.7 & 7.1 & 7.1 & 7.1 & 15.7 & 9.6 & 2.8 \\
\hline
\end{tabular}

Based on the analysis of the results, in most cotton soil samples, mercury levels are higher $(24.1 \mathrm{ppb})$ at the horizon $(0-20)$ of the soil only in the horizon (20-40) with an average rate of $21.5 \mathrm{ppb}$.

Table 3 shows the Hg concentrations of different species of plant material collected on cotton growing soils in $2 \mathrm{KP}$ municipalities.

Based on the results in Table 1, four forage species and okra leaves were collected in the three municipalities: Hyparrhenia involucrata Stapf (HIS), Ipomoea eriocarpa R. $\mathrm{Br}$ (IER), Abelmosehus eseuilleus (L.) Moench (AEM),
Andropogon chinensis (Nees) Merr (ACM) and Rottboellia cochinchinensis (Lour.) WD Clayton (RCL). $\mathrm{Hg}$ concentrations ranged from 6.9 in RCL and ACM forage species to $15.7 \mu g / L$ in okra leaves with an average concentration of $9.6 \mu \mathrm{g} / \mathrm{L}$ and a standard deviation of $2.8 \mathrm{ug} /$ L. the concentration of mercury is higher in okra leaves than in other forage species.

Table 4 below relates to the contamination of cow's milk with residues of $\mathrm{Hg}$. The milk is collected in the peuhl's camps at Pikiré (Piki), Sékogourou (Seko), Makrougourou (Makr) and Gnemasson (Gnem).

Table 4. Comparison of Hg average in cow milk contamination rates with WHO guidelines for drinking water.

\begin{tabular}{lllllllll}
\hline Name & Piki & Seko & Makr & Gnem & Min & Max & Mean & Sd \\
\hline $\mathrm{Hg}(\mu \mathrm{g} / \mathrm{L})$ & 1.1 & 8.7 & 0.8 & 0.4 & 0.4 & 8.7 & 2.8 & 4.0 \\
\hline
\end{tabular}

* WHO standard.

$\mathrm{Hg}$ levels in milk samples ranged from $0.4 \mu \mathrm{g} / \mathrm{L}$ at Gnemasson to $8.7 \mu \mathrm{g} / \mathrm{L}$ at Sekogourou with an average of 2.4 $\mu \mathrm{g} / \mathrm{L}$ and a standard deviation of $3.2 \mu \mathrm{g} / \mathrm{L}$. The high value of the standard deviation shows a strong dispersion of the values. In addition, most of the concentrations are above the WHO standard of $1 \mu \mathrm{g} / \mathrm{L}$ for drinking water. The high mercury content in cows' milk taken in Sékogourou could be explained by the high level of mercury reported in fodder and water, with cows feeding on fodder and water from the environment. All of them, according to Tables 1 to 4 , the maximum values of the recorded concentrations are $8.7 \mathrm{ppb}$, $40.1 \mathrm{ppb}, 616.9 \mathrm{ppb}, 15.7 \mathrm{ppb}, 34.2$, ppb and $26.6 \mathrm{ppb}$ 
respectively in cow's milk, sediment, water, plant material and soil horizons $(0-20) \mathrm{cm}$ and $(20-40) \mathrm{cm}$. Similarly, the average values are $2.4 \mathrm{ppb}, 36.6 \mathrm{ppb}, 180.1 \mathrm{ppb}, 10.2 \mathrm{ppb}$, $22.8 \mathrm{ppb}$ and $21.5 \mathrm{ppb}$, respectively. So we have the ranking in decreasing order as follows: water $>$ sediment $>$ soil $0-20>$ soil 20-40> forage $>$ cow's milk. This classification is consistent with that of murky waters, but in relatively calm waters the concentrations in water have the lowest value
(0.85 ppb).

\subsection{Distribution of Mercury in Environmental and Food Matrices in $2 \mathrm{KP}$}

Table 5 shows the average levels of $\mathrm{Hg}$ in environmental matrices and food in the municipalities of Kérou, Kouandé and Péhunco.

Table 5. Average $\mathrm{Hg}$ ( $p p b$ ) rates in environmental matrices and foods by municipalities.

\begin{tabular}{|c|c|c|c|c|c|c|}
\hline Municipalities/Matrices & Milk & Sediments & Water & Feed & Soil 0-20 & Sol 20-40 \\
\hline Kérou & 1.1 & 19.3 & 139 & 9.9 & 22.3 & 23.6 \\
\hline Kouande & 4.8 & 23.1 & 163.4 & 11.3 & 33 & 23.6 \\
\hline Péhunco & 0.4 & 23.7 & 231.2 & 9.8 & 24 & 17.1 \\
\hline
\end{tabular}

Referring to this table, we observe the highest concentration in Kouandé cow's milk $(4.8 \mathrm{ppb})$ as well as in forage (11.3 ppb) and soil horizons (33.0 and $23.6 \mathrm{ppb})$. Hence the first source of contamination of the cow would be the agricultural source, via soil and fodder. Which gives the following classification: soil $>$ forage $>$ cow's milk. On the other hand, Péhunco has the highest levels in sediment (23.7 $\mathrm{ppb}$ ) and water (231.2 ppb), followed by Kouandé. This could be explained by the presence, in the Mekrou river nest of a point source linked to the ASSGE in Pehunco at the height of Kouyagou according to the investigations results.

This study focused on the agricultural source of $\mathrm{Hg}$ for several reasons including the misuse of agricultural inputs for cotton cultivation. Indeed, cotton growing is by far the first in terms of planting in the municipalities of $2 \mathrm{KP}$, while this crop is the most demanding in terms of use of agricultural inputs and especially herbicides and fungicides. However, $\mathrm{Hg}$ derivatives are used in agriculture in the formulation of herbicides and fungicides. Scientific evidence indicates that $\mathrm{MeHg}$ is used in agriculture as a fungicide to prevent rot [12, 13]. Mexican barley and wheat seeds that had been treated with $\mathrm{MeHg}$ resulted in tens of thousands of deaths among the Iraq population after consuming bread made from these products. The choice of water and sediment sampling points is made by considering the proximity of the water points of the cultivation areas and artisanal and small-scale gold mining sites [1]. More than $90 \%$ of farmers have their fields near a watercourse or body of water in the $2 \mathrm{KP}$ municipalities. These concerns were raised by [14] in Togo and [15] in Benin, who made reference to the nuisance that these bad practices could cause.

Levels of environmental and food matrix contamination vary from one material type to another. The concentrations in water are higher than those of WHO-free surface water $(<0.5$ $\mu \mathrm{g} / \mathrm{L})$ and WHO standards of $1 \mu \mathrm{g} / \mathrm{L}[16]$. The analysis of the concentration variations reveals two trends in the water samples, the rivers with relatively higher concentrations (181.2 to $616.9 \mu \mathrm{g} / \mathrm{L}$ ) and the ponds and dams on the other hand $(0.5$ and $1.3 \mu \mathrm{g} / \mathrm{L})$. Variations observed in high-flow rivers and murky waters are comparable to those observed by [17] who reported 200 to $900 \mu \mathrm{g} / \mathrm{L}$ in the Porto Novo lagoon. In a study conducted in the Mitrovica region of Kosovo in the Trepca and Sitnica rivers, [18] found mercury concentrations of 5 to $8.8 \mu \mathrm{g} / \mathrm{L}$ that are lower than the results of rivers but similar to the results of ponds and dams. [19] reported an average of $1.19 \mu \mathrm{g} / \mathrm{L}$ and significant seasonal variations that are close to the results of pond and dams water. In winter $(1.91 \mu \mathrm{g} / \mathrm{L}),[19]$ found higher values than in spring $(0.14 \mu \mathrm{g} / \mathrm{L})$, summer $(0.01 \mu \mathrm{g} / \mathrm{L})$ and fall $(0.01 \mu \mathrm{g} / \mathrm{L})$. In all cases, all these $\mathrm{Hg}$ concentrations in surface water are higher than those found by [20] with rates ranging from 3 to $19 \mathrm{ng} / \mathrm{L}$ in the St. Lawrence River near Cornwall, Ontario. The heavy contamination of lake and river water in the commune of $2 \mathrm{KP}$ is the result of diffuse pollution from cultivated areas.

Sediment concentrations ranged from 15.5 to $81.1 \mu \mathrm{g} / \mathrm{kg}$ with an average of $30.1 \mu \mathrm{g} / \mathrm{kg}$ and a standard deviation of 23.2 $\mu \mathrm{g} / \mathrm{kg}$. This result is in the range of concentrations obtained by [20] in river sediments (from 15 to $882 \mu \mathrm{g} / \mathrm{kg}$ ) but above the values reported by [21]. Soil horizons are heavily contaminated by mercury, particularly the superficial horizons (24.1 ppb) confirming permanent contact with $\mathrm{Hg}$ chemical pollution and its migration to the water table $(21.5 \mathrm{ppb}$ in the 20-40 horizon). $\mathrm{cm}$ ). The agricultural source of $\mathrm{Hg}$ would be the most important for this reservoir, which is sprayed each year with tons of herbicides and fungicides [22].

Analysis results from plant material samples reveal high levels in forage and okra leaves $(7.1$ to $15.7 \mu \mathrm{g} / \mathrm{L})$ with an average concentration of $9.6 \mu \mathrm{g} / \mathrm{L}$ in the range of values ofliterature. The total concentration of $\mathrm{Hg}$ reported by [20] in $N$. Variegatum ranged from 6.4 to $36.5 \mu \mathrm{g} / \mathrm{kg}$. These results are also consistent with those of [22] and [19]. But [20] reported higher rates on leafy vegetables generally exceeding those of legumes and fruits [22], while [19] showed that after the roots, the leaves are the most mercury-contaminated parts. For the different species studied we have the following order of classification: AEM $(15.7 \mu \mathrm{g} / \mathrm{L})>\mathrm{HIS}(11,4 \mu \mathrm{g} / \mathrm{L})>$ $\operatorname{IER}(9.1 \mu \mathrm{g} / \mathrm{L})>\operatorname{ACM}(7.1 \mu \mathrm{g} / \mathrm{L})=\operatorname{RCL}(7.1 \mu \mathrm{g} / \mathrm{L})$. The mercury level is higher in the AEM species (Okra leaf, Abelmsehus Eseuilleus (L.) Moench which is a high-speed growth plant with leaves that are used for human consumption. Note that the leaves of Abelmsehus eseuilleus (L.) Moench, is grown in association with cotton. This highlights the dangers of food crops in association with 
cotton and confirms the main source identified as the agricultural source. Cow's milk is the least contaminated matrix of our samples. Cattle with the ability to demethylate mercury in the rumen (rumen), beef and milk contain only very low levels of mercury [23]. But these levels are relatively high because they exceed the quality standard of drinking water. However, the presence of $\mathrm{Hg}$ in cow's milk is an evidence of the migration of this chemical pollutant into food webs and the exposure of populations to this pollutant through food. The classification of the average concentrations in the $2 \mathrm{KP}$ municipalities with water in first place of the contaminated matrices is not consistent with the results of the literature [20] that sediments are the preferred accumulations and methylation / demethylation of mercury.

\section{Conclusion}

The results of this study showed that all the targeted matrices showed high levels of mercury but with excessively high levels in surface water. The first source of contamination of the cow would be the agricultural source, via the soil and the fodder. This work shows the presence, in the nest of the Mekrou river, of a point source linked to the ASSGE in Péhunco at the height of Kouyagou. Agriculture and mining are mainly responsible for this pollution. However, the presence of mercury in cow's milk, okra leaves, water and in sediments deserves an in-depth study to identify the chemical forms of this pollutant in the different matrices.

\section{Acknowledgements}

We gratefully acknowledge the advice and assistance of:

1) Dr Andrew A. ERAKHRUMEN, Department of Forest Resources and Wildlife Management/Faculty of Agriculture, University of Benin, Benin City, Nigeria

2) Etiennette DASSI, Responsable of the Environmental Monitoring Laboratory of Ministry of the Environment and Sustainable Development (MCVDD).

This work was supported in part by the Government of Benin through the Environmental Monitoring Laboratory of the Environment and Sustainable Development Ministry.

\section{References}

[1] Dhaouadi, R.; Tarhouni, D.; Louati, A.; Bouhalfaya, R.; Elhafi, O. M., Impacts du mercure (métal trace) sur le milieu marin et les êtres vivants. 2013. Evailable: https://www.google.bj/?gws_rd=cr\&ei=jrrrwonndcwsacrnhng $\mathrm{h} \# \mathrm{q}=$ impacts $+\mathrm{du}+$ mercure $+($ metal + trace $)+$ sur $+\mathrm{le}+$ milieu + mari $\mathrm{n}+\mathrm{et}+\mathrm{les}+\mathrm{etres}+$ vivants.

[2] United Nations Environment Programme (UNEP), Global Mercury Assessment 2013. Sources, Emissions, Releases and Environmental Transport. UNEP. Chemicals Branch 2013, Geneva, Switzerland, 32 p.

[3] Pironne, N.; Cinnirella, S.; Feng, X.; Finkelman, R. B.; Friedli, H. R.; Leaner, J.; Mason, R.; Mukherjee, A. B.;
Stracher, G. B.; Streets, D. G.; and Telmer, K., Global mercury emissions to the atmosphere from anthropogenic and natural sources. Atmospheric Chemistry and Physics 2010, Vol. 10, 5951-5964.

[4] Chasar Lia, C.; Scudder Barbara, C.; Stewart Robin, A.; Bell Amanda, H.; And Aiken George, R., Mercury Cycling in Stream Ecosystems, 3, Trophic Dynamics and Methylmercury Bioaccumulation. Environ. Sci. Technol. 2009, Vol. 43, 27332739.

[5] Oursel, B., Transferts et dynamique des contaminants métalliques en zone côtière. Impact d'une grande agglomération méditerranéenne. 2013, Thèse de doctorale de l'Université de Toulon.

[6] Smith Kirk, R.; Jerrett, M.; Anderson, H. R.; Burnett Richard, T.; Stone, V.; Derwent R.; Atkinson Richard, W.; Cohen, A.; Shonkoff Seth, B. ;Krewski Daniel, C.; Pope Iii A.; Thun Michael, J.; Thurston, G., 2009. Public health benefi ts of strategies to reduce greenhouse-gas emissions: health implications of short-lived greenhouse pollutants. www.thelancet.com Vol 374 December 19/26, 2009.

[7] Ministère de L'agriculture de L'élevage et de la Pêche (MAEP), Statistique de la campagne agricole du Benin, 2007.

[8] Institut National de la Statistique et de l'Analyse Economique (INSAE), 2013.

[9] Biaou, C.; Alonso, S.; Truchot, D., Contamination des cultures vivrières adjacentes et du sol lors d'une pulvérisation d'insecticides sur des champs de coton: cas du triazophos et de l'endosulfan dans le borgou (bénin). Revue Méd. Vét. 2003, Vol. 154, No 5, 339-344.

[10] Voegborlo, R. B.; And Adimado, A. A., Total mercury distribution in different fish species representing different trophic levels from the atlantic coast of ghana. Journal of Science and Technology 2010, Vol. 30, No. 1, 1-91

[11] Cossa and Quémerais Procedures for sampling analysis of mercury in natural waters. Rapport scientifique et technique31E. Centre St Laurent. 1997, 36p.

[12] Amin-Zaki, L.; Elhassani, S.; Majeed, M. A.; Clarkson, T. W.; Doherty, R. A.;Greenwood M., Intrauterine methylmercury poisoning in Iraq. Journal Pediatr1974, Vol.54, No. 5, 587595.

[13] AFSSA (2002), Saisine n 2002-SA-0014 relatif à l'évaluation des risques sanitaires liés à l'exposition au mercure des femmes enceintes allaitantes et des jeunes enfants.

[14] Kanda, M.; Boundjou, G. D.; Wala, K.; Gnandi, K.; Batawila, K. ; Sanni, A.; et Akpagana, K., Application des pesticides en agriculture maraichère au Togo. Journal VertigO - revue électronique en sciences de l'environnement [En ligne] 2013, Vol. 13 No. 1 | avril 2013, mis en ligne le 16 avril 2013. URL: http://vertigo.revues.org/13456 ; 332 DOI $10.4000 /$ vertigo. 13456

[15] Adechian Akinhola, S.; Baco, M. N.; Akponikpe, I., Les pratiques paysannes de gestion des pesticides sur lemaïs et le coton dans le bassin cotonnier du Bénin. Journal VertigOrevue électronique en sciences de l'environnement [En ligne] 2015, Vol. 15, No. 2, 13p.

[16] World Health Organization (WHO), Normes de l'OMS sur l'eau potable, 2006, Mercure http://www.lenntech.fr 
[17] Chouti, W.; Mama, D.; et Alassane A., Caractérisation physicochimique de la lagune de porto-novo (sud bénin) et mise en relief de la pollution par le mercure, le cuivre et le zinc. Journal of Applied Biosciences 2011, Vol. 43, 2882 2890.[18] Kadriu,, S. ; Malollari, I. ; Pula-Beqiri, L. ; Aliu, M. ; Sadiku, M.; Baruti, B. ; et Kelmendi, M., Presence of heavy metals in water and sediment of rivers trepca and sitnica. Journal of Environmental Protection and Ecology2017, Vol. 18, No. 1, 10-21.

[18] Murat, Y.; Aykut Y.; and Fatma S., Heavy Metal Accumulation In the Leaves, Stem and Root of the Invasive Submerged Macrophyte Myriophyllum spicatum L.

(Haloragaceae): An Example of Kadın Creek (Mugla, Turkey). Journal of Braz. Arch. Biol. Techno. 2014, Vol. 57, No. 3, 434-440, May-June 2014 http://dx.doi.org/10.1590/S1516-8913201401962

[19] Thompson-Roberts E., S.; Pick Frances, R.; Hall Gwendy, E.
M., Total Hg in Water, Sediment, and Four Species of Aquatic Macrophytes in the St. Lawrence River, near Cornwall, Ontario. Journal of Great Lakes Research1999, Vol. 25, No. 2, 294-304. https://doi.org/10.1016/S0380-1330 (99)70738-0. /periodique/elements/hg.htm)

[20] Ugbidye, S.; Eneji, I. S.; and Sha'ato R., Determination of Mercury Level in Rana esculenta (Frog), Sediment and Water from River Guma, Benue State Nigeria. Journal of Environment and Earth Science2013, ISSN 2224-3216 (Paper) ISSN 2225-0948 (Online) Vol. 3, No. 12.

[21] USEPA, Mercury in solids and solutions by thermal decomposition, amalgamation, and atomic absorption spectrophotometry, U. S. Environmental Protection Agency, 1997.

[22] United Nations Environment Programme (UNEP), Evaluation mondiale du mercure. PNUE - Substances chimiques Genève, Suisse, 2002, 292 p. 